west, drier seasonal forests in the centre, and different evergreen forests in the east, with the full range of altitudinal vegetation zones throughout.

The photographs are exquisite, the text clear, concise and very informative, full of important and/or interesting facts. There are introductions to Sumatra and Kalimantan, Java and Bali, Sulawesi, the Moluccas, the Lesser Sundas and Irian Jaya, followed by a focus on each of the islands (or groups of islands), illustrating in detail the plants and animals of the national parks in each area, with good maps throughout. There are numerous nice touches, such as a Rafflesia bud early in the volume, one in full flower in the middle and a decaying flower at the end.

The scenic shots - of islands, volcanoes and views from mountains - are especially spectacular; the Indonesian people are featured throughout. In highlighting the treasures of Indonesia, there is a powerful conservation message, with the authors pleading for their salvation, for a more powerful international effort to support the sustainable activities of the Indonesian people, respecting their traditions and life-styles, so that their threatened ecosystems survive.

David I. Chivers Selwyn College, Cambridge

\section{Biotic Diversity in Southern Africa: Concepts and Conservation edited by B. J. Huntley (Oxford University \\ Press, Cape Town, 1989, ISBN 019 5705491, 380 pp., HB£17.50)}

The issue of declining biodiversity has rapidly risen to prominence as a global issue that has captured not only the attention of the scientific community. Following the recent
Rio Earth Summit it has become an important political and economic issue as well. But what is biodiversity? Why do we need it? How much do we need? How do we look after it? These obvious questions make many natural scientists uneasy, and it is encouraging to find a book that makes a bold stab at providing some answers.

Brian Huntley has a reputation for his abilities as a coordinator, catalyst and editor, and this book is proof of those abilities. The book is based on invited review papers presented at a conference at the University of Cape Town in June 1988. The book does not read like a standard compilation of conference proceedings, however, and the papers have been refereed by an internationally respected team of conservation biologists. The papers are grouped into six parts: the first three consider the dynamic nature of biodiversity, human dependence on biodiversity, and the survey, evaluation and monitoring of biodiversity; the last three cover the conservation status of terrestrial, riverine and marine biotas, and review national policy on and corporate involvement in South Africa's natural environment.

My main criticism is that, while the title suggests coverage of southern Africa, the book is very much limited to South Africa. Furthermore, there is scant consideration of the growing international awareness that biodiversity can be best conserved if it can be shown to yield financial and material rewards through sustainable utilization. Zimbabwe can offer some innovative ideas in this department. The title should have been more specific or the book's geographical coverage extended over the entire southern African subregion.
Nevertheless, for wildlife conservationists working in South Africa or with interests in South Africa's biota, I can highly recommend this book. It contains clear explanations of key concepts relevant to the biodiversity issue, reviews the relevant methodology, and provides status reports for the major ecosystems.

Johan du Toit University of Zimbabwe

\section{CONSERVATION HISTORY}

Fraser Darling in Africa: A
Rhino in the Whistling Thorn edited by John Morton Boyd (Edinburgh University Press, Edinburgh, 1992, ISBN 074860368 9, 307 pp., HB £25)

John Morton Boyd has edited the African diaries of Sir Frank Fraser Darling, adding a summary and some excellent colour photographs. The book will be enjoyed by all serious naturalists, particularly those who have an interest in the areas of Africa covered in his studies: Zambia, Kenya, Northern Tanzania and the Sudan.

Having been privileged to accompany Sir Frank on one of those surveys, I experienced at first hand the wealth of wisdom he had to offer. All the more pity, then, that these journals are mainly diaries of events and observations. The gems of wisdom that do appear are few and far between, although the editor has helped to highlight them explicitly.

The journals were written mainly as letters to his wife and therefore do not always bring out the efficacy of his findings. They do, however, provide an insight into his immediate reactions to the African scene as it 